\title{
ASSESSMENT OF LOCAL PEOPLE RESPONSE TOWARD SOCIAL, ECONOMIC AND ENVIRONMENTAL IMPACTS OF TOURISM AND THE ENVIRONMENTAL DIRECTION AMONG TOURISTS VISITING OHRID AND STRUGA, REPUBLIC OF MACEDONIA
}

DOI: http://dx.doi.org/10.18509/GBP.2020.28

UDC: 338.48-052]:005.52:005.33(497.771/.772)

338.484/.485(497.771/.772)

\author{
Goran Chakarevski \\ Stojce Adjioski \\ Muthulakshmi AL \\ Ninoslav Marina \\ University of information science and technology St. Paul the Apostle, \\ Ohrid, North Macedonia
}

\begin{abstract}
Tourism today is a leisure activity of the common people and tourists visit for its natural and attractive beauty. Lake Ohrid, located between Republic of Macedonia and Albania is an ancient spectacular quality of lake water among long-lived lakes of the world. Due to this fact, the lake is also known as a "Museum of Living Fossils". Initially, this study emphasis on the resident's response about social, economic and environmental impacts of tourism. Furthermore, evaluated the tourists profile and the environmental orientation of tourists visiting the vicinity of Ohrid and Struga. Primary data were collected on the basis of quantitative and qualitative responses of tourists through questionnaire. In addition, secondary data were also collected from the official website of Ministry of Tourism and different journals and books that are included in this research work. In SWOT analysis, the tourism was evaluated on the internal strengths and weaknesses that would improve or reduce its capacity to attract visitors. Likewise, the external environment can initiate various opportunities or threats of Ohrid and Struga tourism. According to the survey, it revealed most of the respondents have negative perceptions for social impacts of tourism, although they are fascinated to meet people especially from foreign countries. With regards to economic impacts, tourism does have positive impact that lead to the development of their economy. However, crowded public places, traffic jamming and noise pollution were found to be the negative aspects of environmental impacts. The findings also indicate that Ohrid and Struga are currently in its development stage and could provide suggestions to Ministry of Tourism based on SWOT Analysis. It is expected that the present study will help to develop the sustainable and management of tourism in Ohrid and Struga, Republic of Macedonia.
\end{abstract}

Keywords: Lake Ohrid, Struga, Tourism impacts, SWOT analysis

\section{INTRODUCTION}

Tourism is the world's fascinating industry. With the continuous development of tourism, the impact on the environment is frequently emerging, including both negative and positive phases. Lake Ohrid, located between Macedonia and Albania (Fig. 1), is an antique lake in the world, the only one long-lived lakes in Europe that have providing around-the-clock freshwater for more than 1 million years [1], [2] and [3]. It ports a large 
number of relict and endemic species [4] and [5]. Lake Ohrid is momentous not only in scientific field but also an economic perspective, therefore the lake and the Ohrid town were protected by UNESCO [6]. Furthermore, annually up to 50,000 tourists visiting the Lake Ohrid [7].

Tourism is exclusively dependent on the environment. Assets from mother nature (beaches, seas, mountains, lakes, rivers etc.) and man-made resources (historic cities, heritage buildings and sites, memorials etc.) act as the primary source of tourism [8]. A little filth of the primary sources is expected to a degeneration of tourism activities. The present study is based on the intention to promote sustainable tourism based on visitor's responsible and awareness about the environment at a destination. The study takes into account different profile of the tourists visiting and their knowledge about the environmental orientation. Finally, to identify the perceptions of residents toward social, economic and environmental impacts of tourism. Local communities are known as the key stakeholders in leisure and tourism management. Plethora of studies have been carried out by researchers to develop their countries, taking into considering the importance of resident's feedback in tourism.

\section{AIMS AND OBJECTIVES}

The present study is constructed on responsible tourist activities to support ecological tourism performs in Ohrid and Struga. The study has the following objectives:

1. To investigates tourists profile and the environmental orientation among tourists visiting.

2. To estimate the local people perceptions toward social, economic and environmental impacts of tourism in the vicinity of Ohrid and Struga.

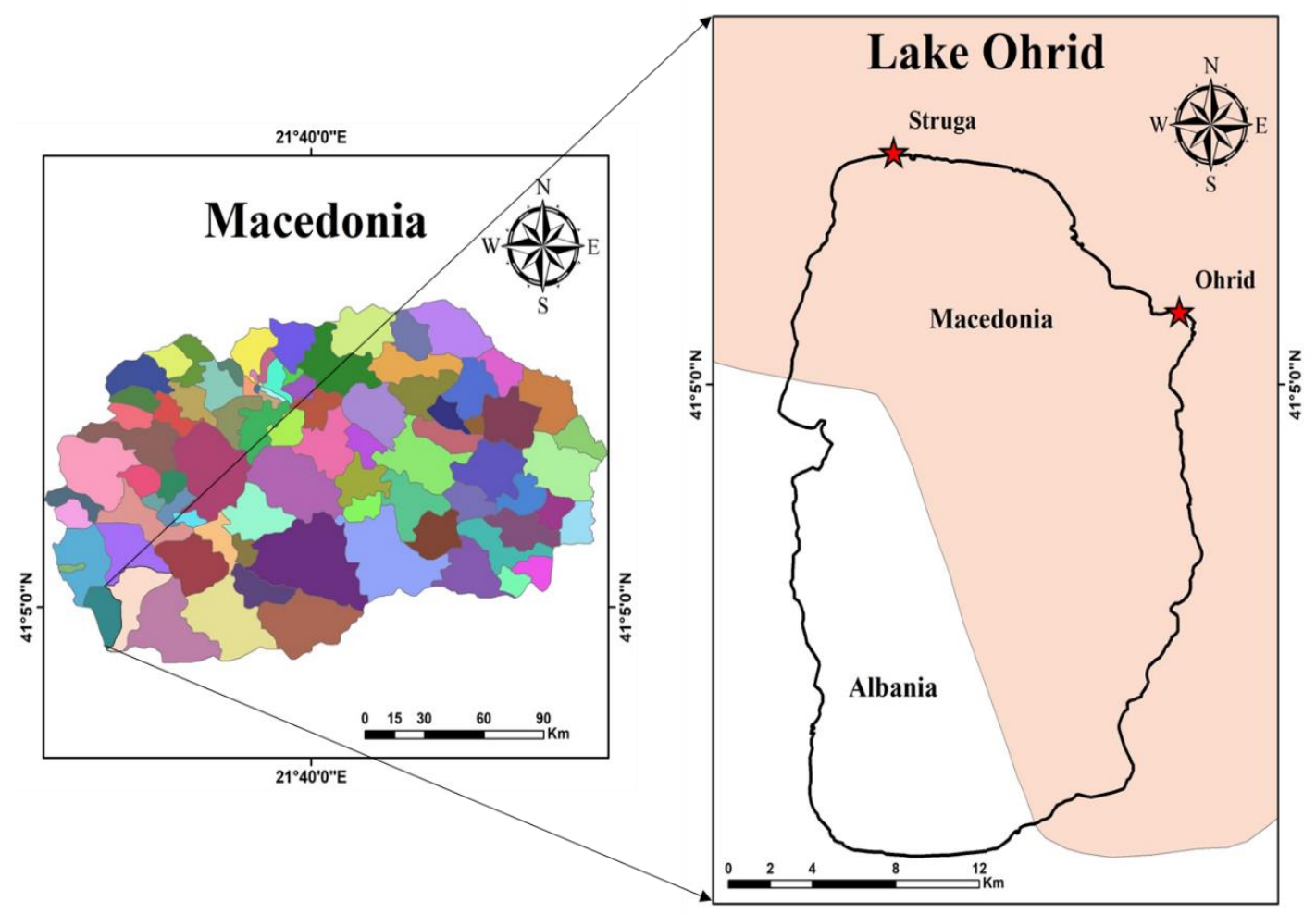

Figure 1. Aerial view of survey area - Ohrid and Struga 


\section{THE METHODS OF THE STUDY}

\section{Research design}

The present survey follows the sequential explanatory research design in mixed research methods. As a result of Creswell [9], mixed methodology involves the use of both qualitative and quantitative approaches to create it stronger method.

\section{Scale development}

According to Iqbal Ahmad Bhat [10], in tourism studies the five-point Likert scales used as the most common scale in tourism where respondents are supposed to expression their agreement or disagreement with a statement regarding a certain object.

\section{Instrumentation}

To improve the data collection instrument (questionnaire) which should be immaculate and logical. In the present study the questionnaire was prepared keeping in interpretation of the study area and related works conducted before based on the literature review. Bagri \& et al [11] and Pereira [12] were found useful in constructing the questionnaire. The first section of the questionnaire is based on the tourist's profile and the environmental orientation among tourists visiting. The second section uses the local people perceptions toward social, economic and environmental impacts of tourism. The data has been collected at major tourist terminals in the Lake Ohrid such as Ohrid and Struga and the survey was conducted in the month of November and December 2019.

\section{Sampling Size}

In the present study, an overall of 300 questionnaires were circulated for both tourist as well as the local community to obtain the information at the places of visiting (Ohrid and Struga). The number of filled in questionnaires received were 287 and were found useful for analysis. Primary data and secondary data have been presented in this study to support the development of tourism in Republic of Macedonia.

\section{SWOT Analysis}

A SWOT analysis is an analytical model, especially developed for numerous business approach. SWOT stands for strengths, weaknesses, opportunities, and threats, strategy and programs. Strengths and weaknesses are internal issues of organization and opportunities and threats are external environmental issues. It is a descriptive study with a qualitative approach. The purpose of this analysis is to understand the experience of the subject such as their behavior, perception, motivation, and actions [13] and [14]. It provides the information on how the native government should develop the tourism as potentials. To perform the SWOT analysis, we have collected appropriate information from the secondary data for example research journals, articles, foremost newspapers, websites and government annual reports [14].

\section{RESULTS AND DISCUSSION}

The first part of the study detailed with profiling of tourists and the environmental orientation. Table 1 provides the results of profiling of tourists and Figure 1 displays the rate of distribution of environmental orientation of tourists. From 287 respondents, 53\% was from Ohrid and 47\% from Struga. In Ohrid, Male and female respondents created $50 \%$ of the sample. $42 \%$ are less than 30 years old whereas $31 \%$ are participated from 
age between 31 to 50 years old. $54 \%$ of them are married, while $46 \%$ are singles. With reference to their educational level, $19 \%$ has secondary school qualification, $50 \%$ of the respondents have degree as the highest level of education attained and $23 \%$ have a higher degree. In addition to that $38 \%$ of contributed from government and private profession, although $12 \%$ of occupation based on their own business. With respect to monthly income, $54 \%$ of the respondents stated above $€ 1500$ while $46 \%$ of respondents indicated a monthly income of less than $€ 1500$.

Table 1. Tourist profiling in Ohrid and Struga

\begin{tabular}{|c|c|c|c|c|}
\hline \multirow{2}{*}{ S.No. } & \multirow{2}{*}{$\begin{array}{c}\text { Demographic } \\
\text { variables } \\
\end{array}$} & \multirow{2}{*}{$\begin{array}{l}\text { Category of } \\
\text { respondents }\end{array}$} & \multicolumn{2}{|c|}{ Percentage } \\
\hline & & & Ohrid & Struga \\
\hline \multirow{2}{*}{1} & \multirow{2}{*}{ Nationality } & Macedonian & $4 \%$ & $10 \%$ \\
\hline & & Foreign & $96 \%$ & $90 \%$ \\
\hline \multirow{2}{*}{2} & \multirow{2}{*}{ Gender } & Male & $50 \%$ & $56 \%$ \\
\hline & & Female & $50 \%$ & $44 \%$ \\
\hline \multirow{2}{*}{3} & \multirow{2}{*}{ Marital status } & Married & $54 \%$ & $57 \%$ \\
\hline & & Un-married & $46 \%$ & $43 \%$ \\
\hline \multirow{3}{*}{4} & \multirow{3}{*}{ Age } & Up to 30 & $42 \%$ & $43 \%$ \\
\hline & & $31-50$ & $31 \%$ & $29 \%$ \\
\hline & & Above 50 & $27 \%$ & $28 \%$ \\
\hline \multirow{4}{*}{5} & \multirow{4}{*}{ Education } & Secondary & $19 \%$ & $24 \%$ \\
\hline & & Graduation & $50 \%$ & $54 \%$ \\
\hline & & Post-graduation & $23 \%$ & $19 \%$ \\
\hline & & Others & $8 \%$ & $3 \%$ \\
\hline \multirow{4}{*}{6} & \multirow{4}{*}{ Occupation } & Government & $38 \%$ & $30 \%$ \\
\hline & & Private & $38 \%$ & $46 \%$ \\
\hline & & Business & $12 \%$ & $16 \%$ \\
\hline & & Others & $12 \%$ & $8 \%$ \\
\hline \multirow{2}{*}{7} & \multirow{2}{*}{$\begin{array}{l}\text { Monthly } \\
\text { income }\end{array}$} & Below $€ 1500$ & $46 \%$ & $60 \%$ \\
\hline & & Above $€ 1500$ & $54 \%$ & $40 \%$ \\
\hline
\end{tabular}

Tourist profiling at Struga (Table.1), 90\% of foreigners and 4\% of Macedonian tourist visiting Struga were recorded in tourist profiling. Male respondents $56 \%$ and female respondents $44 \%$. The martial status of the respondents $57 \%$ married and $43 \%$ unmarried. Up to 30 years old $43 \%$ of the respondents, $29 \%$ response from 31-50 years old and $28 \%$ from above 50 years old. With reference to their educational level, $24 \%$ has secondary school qualification, while $54 \%$ and $19 \%$ of the respondents have a degree and a higher degree respectively. According to employment, $30 \%$ of the respondents from government sectors, $46 \%$ of tourist have jobs in private organization. $60 \%$ of the respondents reported their monthly income scale overhead $€ 1500$ however $40 \%$ of respondents specified a monthly income of lower $€ 1500$.

With reference to the environmental orientation, to know the tourists understanding level towards environment were measured on a five-point Likert scale (five-point scale) [10]. The results based on frequency distribution are given in Figure 2. The results of distribution expressed that majority of the tourists either strongly agree or agree on the four statements. These statements are: When humans interfere with nature, it often produces disastrous consequences (2), Humans are severely abusing the earth (3), The earth has plenty of natural resources if we just learn to how to develop them (4) and Does educational background and social status play a role in tourist environmental impact awareness? (7). It can be concluded from the respondents showed agreement to the four statements, disagreement and neither agree or nor disagree to three statements 
respectively. As a result, it predicts the positive and negative approach towards the environmental view [15], [16], [17] and [18].
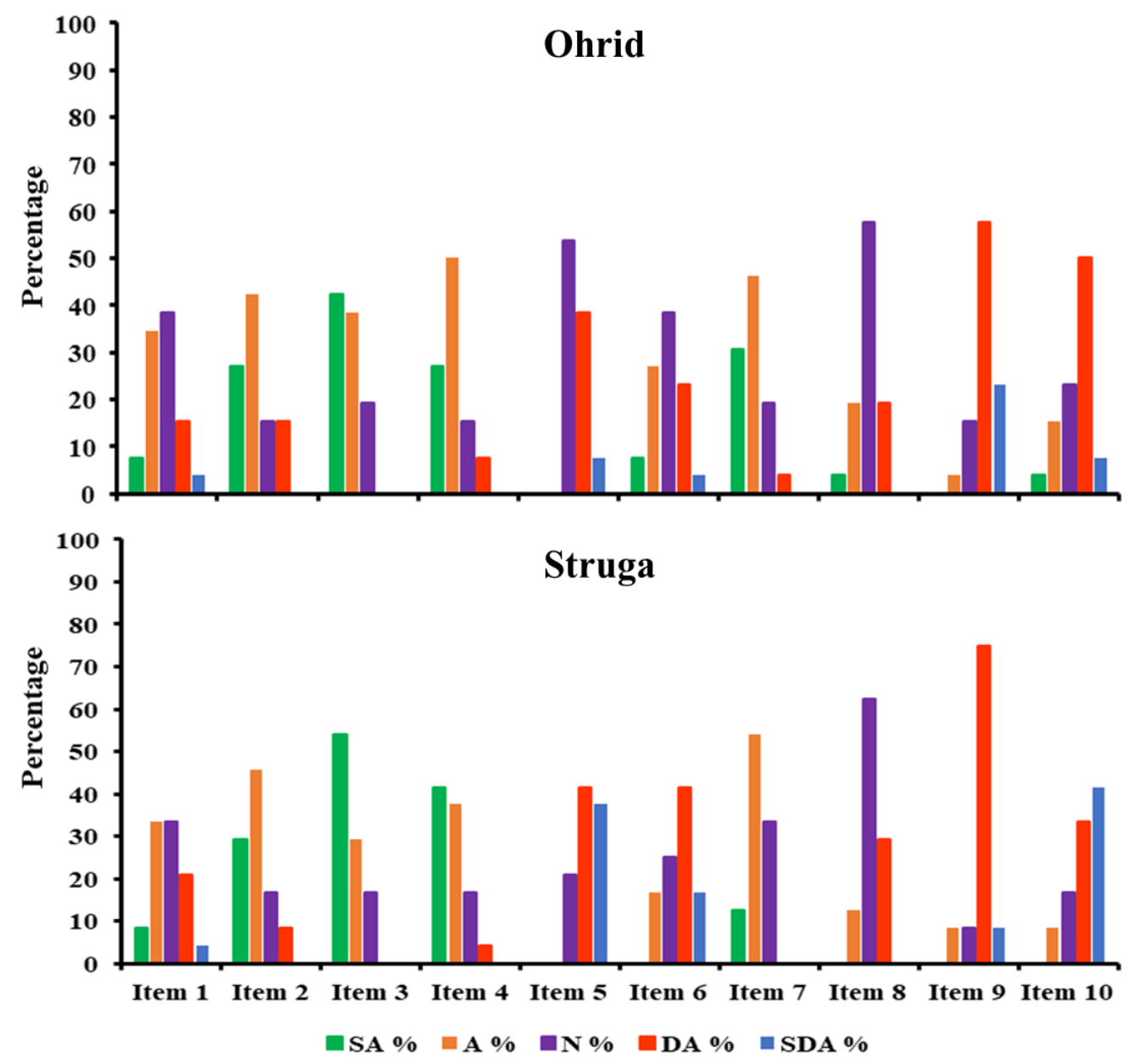

Item 1. Humans have the right to modify the natural environment to suit their needs; Item 2 . When humans interfere with nature, it often produces disastrous consequences; Item 3. Humans are severely abusing the earth; Item 4 . The earth has plenty of natural resources if we just learn to how to develop them; Item 5. Plants and animals have as much right as humans to exist; Item 6.The balance of nature is strong enough to manage with the effects of modern industrial nations; Item 7. Does educational background and social status play a role in tourist environmental impact awareness?; Item 8 . The earth is like a space ship with very limited room and resources; Item 9. Public facilities are kept at a better standard (Like traffic control, waste disposal,); Item 10. The status of water quality of Lake is exceptional

Figure 2: Occurrence of circulation of environmental orientation of tourists

Interviews with local communities toward tourism in the area, items about economic, social and environmental impacts of tourism were studied. Figure 3 shows community perceptions toward the economic, social and environmental impacts of tourism. The following economic impacts mostly positive response by local populations, such as "tourism leads to more investment and spending", "our standard of living is increasing considerably by tourism", "prices are increasing because of tourism", and "tourism creates job opportunities". With reference to social impacts are generally negative response except "meeting tourists is a valuable experience". Findings about environmental impacts, usually position reaction by residents is "tourism provides an incentive for restoration of heritage", "tourism causes crowded public places", "traffic 
jamming, air pollution and noise increase by tourism", and 'tourism destroys the natural environment". However, the negative response of environmental impacts is "public facilities are kept at a better standard". As a result, there are no significant differences between the Ohrid and Struga based on social, economic and environmental impacts of tourism.
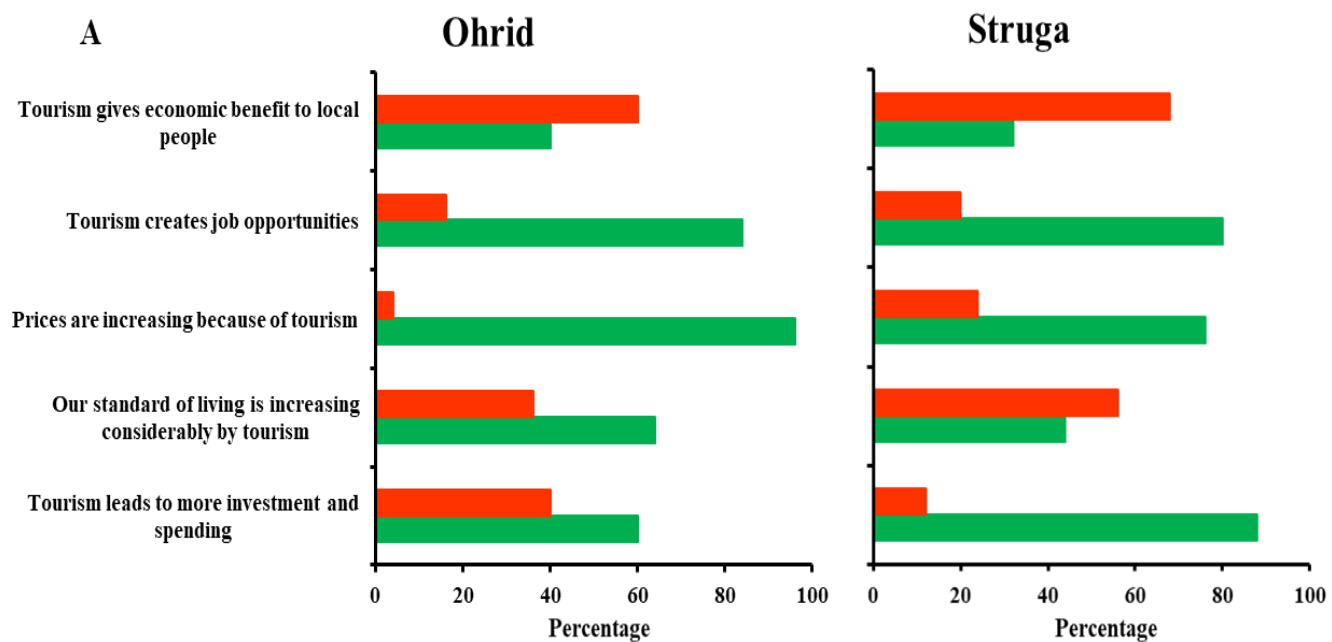

B

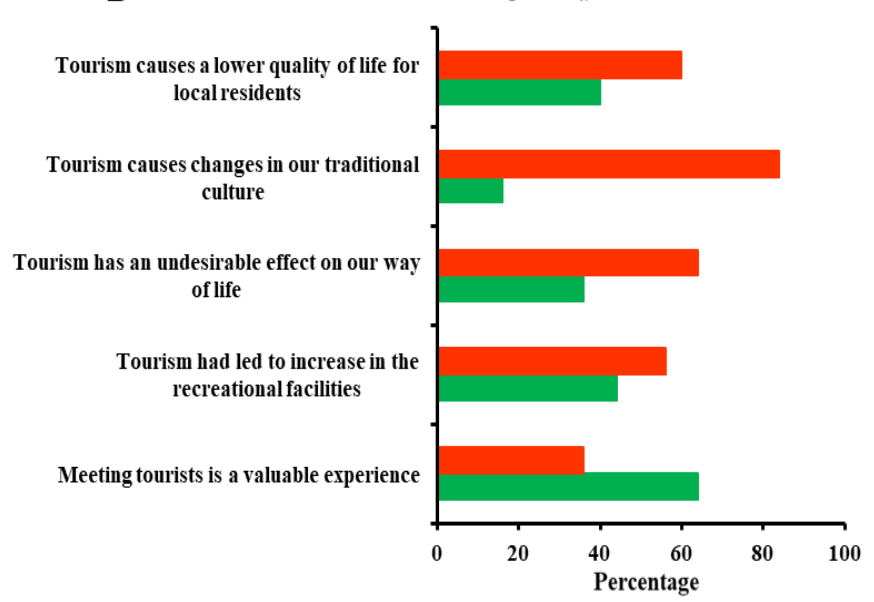

C

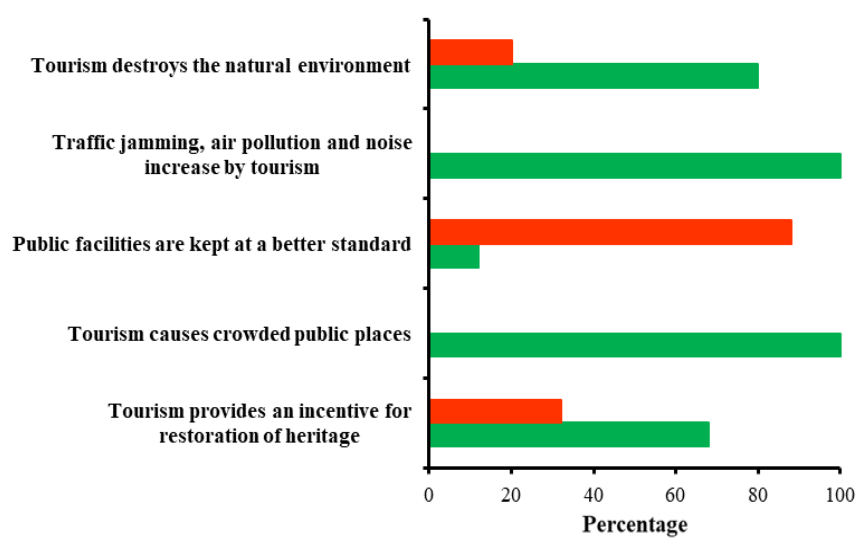

Ohrid

Negative Respons

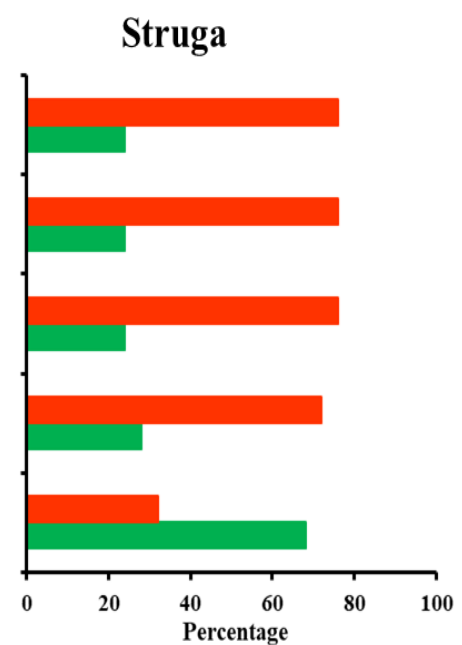

Struga

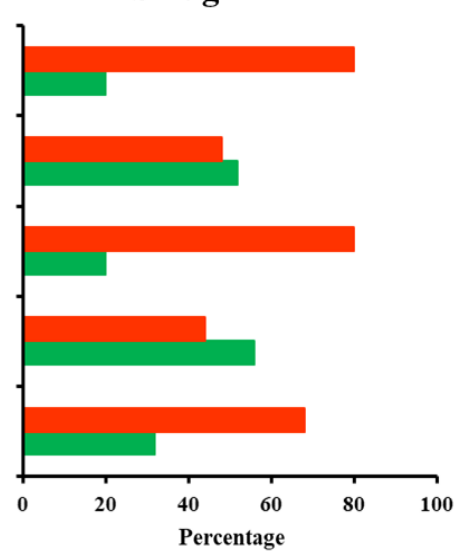

Positive Response

Figure 3. Community estimations toward tourism impacts:

A) Economic Impacts, B) Social Impact and C) Environmental Impact 
Table 2. SWOT analysis for tourism development strategy

\begin{tabular}{|c|c|}
\hline $\begin{array}{l}\text { Opportunities } \\
\text { - Increasing interest in individual travel } \\
\text { - Lake Ohrid has the prospective to become one } \\
\text { of the most popular tourism destinations in } \\
\text { Southeastern Europe } \\
\text { - Progressive development in tourism will lead } \\
\text { to an increasing income from the tourism } \\
\text { industry, will create new jobs and will } \\
\text { stimulate additional investment } \\
\text { - Use the further approach towards the EU for } \\
\text { the development of business tourism } \\
\text { - Establishment of a geopark in the region } \\
\text { - Opportunities for seasonal educational } \\
\text { activities (e.g., nature-focused summer } \\
\text { schools) - With the development of tourism, traditional } \\
\text { handicrafts such as woodworks, carpets, } \\
\text { handcrafts, and ornaments can be marketed to } \\
\text { provide additional income to the local society }\end{array}$ & $\begin{array}{l}\text { Weaknesses } \\
\text { - Ohrid and Struga is still a relatively unknown } \\
\text { tourism destination outside the country } \\
\text { - High seasonality in the main vacation } \\
\text { destinations } \\
\text { - Lack of direct flight connections to Ohrid } \\
\text { - Limited financial and human resources within } \\
\text { the tourism department } \\
\text { - Low annual marketing budget in comparison } \\
\text { to other countries } \\
\text { - Decreasing number of overnights by domestic } \\
\text { travelers } \\
\text { - Less subsidy program for tourism attractions } \\
\text { facilities } \\
\text { - Lack of Qualified Human Resources } \\
\text { - Lack of Tourism Promotion } \\
\text { - Poor quality of some tourism facilities (e.g. } \\
\text { spas, camping grounds) }\end{array}$ \\
\hline
\end{tabular}

Nevertheless, on the environmental impacts, most of the respondents consider that there will be negative impacts on the environment. For example, increased traffic jam, cramped area, air and noise pollution and damage of natural environment by tourists during the tourist season. Hence, many of them believed that tourism have created more jobs opportunities to local people. With regards to social impact of tourism most of the respondents have positive opinions and said that they are happy to meet tourists especially from other countries. Regarding a SWOT analysis, taking into account all aspects of the development of tourism, a SWOT analysis matrix portrays the condition of tourism in Ohrid and Struga (Table 2). According to the SWOT analysis [19], [20] and [21], which contribute to a sustainable development program for the region, is summarized in Table 2. The results revealed that the strengths and weaknesses of tourism reflect the internal 
factors and opportunities supported by the government, whereas threats are mostly related to the new competitors.

\section{CONCLUSION}

Tourism has a momentous position in Macedonia, which has made a spectacular aid to the development of economic status of the country, in addition to that, we must take care of natural resources for sustainable tourism. For this reason, this study addresses the issues of environmental orientation tourism and its positive and negative impacts, through residents' perspective about social, economic and environmental impacts of tourism. Results showed that respondents view more favorable for economic impacts of tourism, followed by environmental impacts and social impacts. Nevertheless, general public believed that tourism has not yet produced sufficient financial profits for local people, on the other hand they agreed that tourism has provided job opportunities. With regards to the SWOT analysis, it will be useful to conduct further studies on the sustainable tourism and suggests that Ohrid and Struga needs further value creations to develop the outstanding tourism activities.

\section{REFERENCES}

[1] Meybeck M, Global distribution of lakes. In Physics and chemistry of lakes, eds. A. Lerman, D. Imboden, and J.R. Gat, pp. 1-32. Berlin, Heidelberg, Germany: Springer, 1995.

[2] Gorthner A, What is an ancient lake? In Speciation in ancient lakes, eds. K. Martens, B. Goddeeris, and G. Coulter, pp. 97-100. Archiv für Hydrobiologie—Advances in Limnology 44, 1994.

[3] Martens G, Coulter G, Goddeeris B, Speciation in ancient lakes-40 years after Brooks. In Speciation in ancient lakes, eds. K. Martens, B. Goddeeris, and G. Coulter, pp. 75-96, Archiv für Hydrobiologie-Advances in Limnology 44, 1994.

[4] World Conservation Monitoring Centre, Freshwater biodiversity: A preliminary global assessment, eds. B. Groombridge and M. Jenkins. WCMC- World Conservation Press. Cambridge, UK, 1998.

[5] Duker L, Borre L, Biodiversity conservation of the world's lakes: A preliminary framework for identifying priorities. LakeNet Report Series, Number 2. Monitor International, Annapolis, Maryland USA, 2001.

[6] UNESCO, Ohrid Region with its cultural and historical aspect and its natural environment. http://whc.unesco.org., 1979.

[7] Andreas Matzinger, Martin Schmid, Elizabeta Veljanoska-Sarafiloska, Suzana Patceva, Dafina Guseska, Bernd Wagner, Beat Mu“ller, Michael Sturm, Alfred Wu"est, Eutrophication of ancient Lake Ohrid: Global warming amplifies detrimental effects of increased nutrient inputs. Limnol. Oceanogr. 52(1): 338-353, 2007.

[8] Niko Koncul, Environmental Issues and Tourism. Ekon. Misao Praksa Dbk. God Xvi. Br. 2:157-166, 2007.

[9] Creswell JW, Research design: Qualitative, quantitative, and mixed method approaches. New Delhi: SAGE Publications 2009.

[10] Iqbal Ahmad Bhat, A Study on Environmental Orientation among Tourists Visiting Kashmir Valley, Journal of Tourism, Volume XIX, No. 1, 2018.

[11] Bagri SC et al, Environmental orientation and ecotourism awareness among pilgrims, adventure tourists, and leisure tourists. Tourism Preliminary Communication,57(1): 55-68, 2009. 
[12] Perera Polwattage K, Marketing forest based ecotourism in Sri Lanka: Predicting the ecotourism behaviour and defining the market segment through behavioural approach. Unpublished Ph.D. dissertation, Louisiana State University, 2011.

[13] Moleong J Lexy, Metodologi penelitian kualitatif, 2007.

[14] Kee Mun Wong, Peramarajan Velasamy, Tengku Nuraina Tengku Arshad, Medical Tourism Destination SWOT Analysis: A Case Study of Malaysia, Thailand, Singapore and India, SHS Web of Conferences 12, 01037, 2014.

[15] Corral-Verdugo V Armendáriz LI, The "New environmental paradigm"in a Mexican community. Journal of Environmental Education, 31(3): 25-31, 2000.

[16] Dunlap RE, Van Liere K, Mertig A, Jones RE, Measuring endorsement of the New Ecological Paradigm: a revised NEP scale. Journal of Social Issues, 56: 425-442, 2000.

[17] Kim H, Borges MC, Chon J, Impacts of environmental values on tourism motivation: the case of FICA, Brazil. Tourism Management, 27(5): 957- 967, 2006.

[18] Liu J, Ouyang Z, Miao H, Environmental attitudes of stakeholders and their perceptions regarding protected area-community conflicts: a case study in China. Journal of Environmental Management, 91(11): 2254-2262, 2010.

[19] Helms MM, Nixon J, Exploring SWOT analysis-where are we now? A review of academic research from the last decade. J. Strateg Manag 3(3):215-251, 2010.

[20] Hosseini SM, Maher A, Safarian O, Ayoubian A, Sheibani-Tehrani D, Amini-Anabad H, Hashemidehaghi Z, Development strategy of health tourism in Iran. International Journal of Travel Medicine and Global Health, 3(4):153-158, 2015.

[21] Kim S, Lee J, Jung J, Assessment of medical tourism development in Korea for the achievement of competitive advantages. Asia Pacific Journal of Tourism Research, 18(5): 421445, 2013. 